\title{
Occurrence of urogenital mycoplasmas in men with the common genitourinary diseases
}

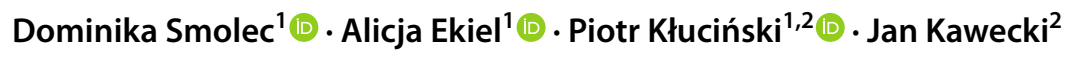

Received: 11 June 2021 / Accepted: 19 September 2021 / Published online: 24 September 2021

(c) The Author(s) 2021

\begin{abstract}
Many serious and fatal infections with urogenital mycoplasmas in immunocompromised patients have been reported. $M$. genitalium is recognized as a cause of male urethritis and other common genitourinary diseases. The aim of the study was to estimate prevalence of urogenital mycoplasmas which can cause complications in men with common genitourinary diseases. Study included 85 men with genitourinary tract carcinoma $(n=35)$, urolithiasis $(n=36)$, and BPH (benign prostatic hyperplasia) $(n=14)$. The control group consisted of 50 healthy men. FVU (first void urine) samples were examined by PCR for the presence of urogenital mycoplasmas DNA. Occurrence of urogenital mycoplasmas was significantly more common in study group compared with control 24/85 (28.2\%) and 7/50 (14\%), respectively $(p=0.05)$. In men with urolithiasis, positive results for mycoplasmas DNA were significantly more frequent than in control: $33.3 \%$ vs. $14 \%(p<0.05)$. In patients with urolithiasis DNA of $U$. urealyticum was most often found, while in the genitourinary carcinoma and BPH groups, $U$. parvum was more frequent. Incidence of $M$. fermentans was also significantly higher in the urolithiasis group vs. control $(p=0.03)$. A higher percentage of positive results for urogenital mycoplasma DNA in study group has been found. Further studies are required to confirm the role of urogenital mycoplasmas in the development of infectious complications among patients with urolithiasis, genitourinary carcinoma, and BPH.
\end{abstract}

Keywords Mycoplasma $\cdot$ Ureaplasma $\cdot$ Genitourinary tract carcinoma $\cdot$ Urolithiasis $\cdot$ Benign prostatic hyperplasia

\section{Introduction}

Urogenital mycoplasmas are commonly found as a part of the normal microbiome of the human urogenital tract. Some of them, mainly Mycoplasmoides genitalium (previous Mycoplasma genitalium) [1], are recognized as a cause of urethritis and risk factor of developing prostatitis, epididymitis, cervicitis, pelvic inflammatory disease (PID), and bacterial vaginosis (BV); they can have a negative impact on fertility and may be cause of pathological course of pregnancy, as well as low birth weight of the newborn

Responsible Editor: Jorge Luiz Mello Sampaio

Dominika Smolec

drady@sum.edu.pl

1 Department of Medical Microbiology, Faculty of Medical Sciences in Katowice, Medical University of Silesia, Medyków 18 Street, 40-752 Katowice, Poland

2 Med Holding Emil Michalowski Specialist Hospital, Katowice, Poland
[2]. Urogenital mycoplasmas may be also an etiological factor of opportunistic infections in patients with genitourinary system and other diseases, especially in patients with a decreased immunity resulting from the underlying disease or ongoing treatment. In patients treated with peritoneal dialysis, hyperammonemia, periaortic abscess following heart-lung transplantation, peritonitis Ureaplasma urealyticum, and Metamycoplasma hominis (previous Mycoplasma hominis) [1] mainly are among the etiological agents of infections [3-5]. Other species, such as Mycoplasmopsis fermentans, Malacoplasma penetrans, and Mycoplasmoides pirum (previous Mycoplasma fermentans, Mycoplasma penetrans, Mycoplasma pirum) [1], are rarely considered in the studies of human biological materials.

Our study aimed to estimate prevalence of urogenital mycoplasmas (Mycoplasma spp. and Ureaplasma spp.) due to the possibility of complications in patients with genitourinary cancer, urolithiasis, and benign prostatic hyperplasia (BPH) compared to control group. To our knowledge, this is the first type study in Poland. 


\section{Patients and methods}

\section{Patients}

The study included 85 men with genitourinary tract diseases. All patients were under care of Med Holding Emil Michalowski Specialist Hospital (urology hospital in the southern Poland). Three groups of men were distinguished. First, patients with genitourinary cancer (prostate cancer, bladder cancer, and kidney cancer), $(n=35$, mean age $67 \pm 9.0)$ were at the diagnostic stage before any specialized oncological treatment. Second group, patients with urolithiasis $(n=36$, mean age $49 \pm 12.2$ ), and the third group, men with $\mathrm{BPH}$ $(n=14$, mean age $65 \pm 7.0)$. All 85 men were screened for the past history of diseases and laboratory test: morphology (blood cell count) and general urinalysis. The characteristics of patients in study groups are presented in the table (Table 1).

The control group consisted of sexually active, healthy men $(n=50$, mean age $47 \pm 16.1)$ without subjectively experienced symptoms from the urogenital tract. All included men gave informed consent for the study.

Table 1 The characteristics of patients

\begin{tabular}{|c|c|c|c|c|}
\hline & $\begin{array}{l}\text { Geni- } \\
\text { tourinary } \\
\text { cancer } \\
(n=35)\end{array}$ & $\begin{array}{l}\text { Urolithiasis } \\
(n=36)\end{array}$ & $\begin{array}{l}\mathrm{BPH} \\
(n=14)\end{array}$ & $\begin{array}{l}\text { Total } \\
(n=85)\end{array}$ \\
\hline Age (years) & $67 \pm 9.0$ & $49 \pm 12.2$ & $65 \pm 7.0$ & $47 \pm 16.1$ \\
\hline \multicolumn{5}{|c|}{ Selected laboratory parameters } \\
\hline \multicolumn{5}{|l|}{ Urine } \\
\hline $\begin{array}{l}\text { Leukocyturia } \\
>5\end{array}$ & $10(4)$ & $23(14)$ & $4(0)$ & $37(18)$ \\
\hline $\begin{array}{l}\text { Hematuria } \\
{[>3 \mathrm{RBC}]}\end{array}$ & $9(4)$ & $20(11)$ & $3(0)$ & $32(15)$ \\
\hline \multicolumn{5}{|l|}{ Blood } \\
\hline $\begin{array}{l}\text { Leukocytosis } \\
N:>11000 / \mu \mathrm{L}\end{array}$ & $3(0)$ & $5(1)$ & 0 & $8(1)$ \\
\hline $\begin{array}{l}\text { PSA } \\
>4 \mathrm{ng} / \mathrm{ml}\end{array}$ & $12(5)$ & 0 & $6(2)$ & $18(7)$ \\
\hline \multicolumn{5}{|l|}{ Other diseases } \\
\hline Hypertension & $19(9)$ & $13(5)$ & $7(2)$ & $39(16)$ \\
\hline $\begin{array}{l}\text { Cardiological } \\
\text { diseases }\end{array}$ & $9(0)$ & $2(0)$ & $2(0)$ & $13(0)$ \\
\hline Smoking & $3(1)$ & 0 & 0 & $3(1)$ \\
\hline Type 2 diabetes & $2(0)$ & 0 & $2(0)$ & $4(0)$ \\
\hline
\end{tabular}

The results show arithmetic mean \pm SD or number (\%) of patients with positive results for mycoplasma detection

Total, patients with the following: genitourinary cancer, urolithiasis, $\mathrm{BPH}$

$B P H$, benign prostatic hyperplasia

$P S A$, prostate-specific antigen
This study was approved by Bioethical Commission of the Medical University of Silesia in Katowice (KNW/0022/ KB1/48/14, KNW/022/KB1/48/I/14/16, KNW/0022/ KB1/48/II/14/16/17). Exclusion criteria of patients were based on lack of consent, antibiotic therapy and/or chemotherapy and antifungals (at least 4 weeks before examination), diagnosed STI, and the catheter and endoscopic surgery in the urogenital tract (at least 4 weeks before examination).

\section{Specimens}

Patients were informed about the urine collection instructions. Samples of morning FVU (first void urine) were collected $(5-10 \mathrm{~mL})$ in sterile plastic container and transported at $+4{ }^{\circ} \mathrm{C}$ to the Department of Medical Microbiology Medical University of Silesia in Katowice, Poland.

\section{Methods}

DNA extraction was done from the pellet obtained after centrifugation $\left(15000 \mathrm{~g}, 30 \mathrm{~min}\right.$, at $\left.4{ }^{\circ} \mathrm{C}\right)$ of $4 \mathrm{ml} \mathrm{FVU} \mathrm{using}$ Gene MATRIX, Bacterial \& Yeast Genomic DNA Purification Kit (EURx). Species identification was performed by the polymerase chain reaction (PCR) using specific primers for U. urealyticum, U. parvum, M. hominis, M. fermentans, and M. pirum (Table 2) [6-8]. Amplifications were conducted using Taq PCR Core Kit (Qiagen Inc.) in thermocycler Mastecycler (Eppendorf AG). Negative samples were checked for presence of amplification inhibitors by PCR reactions with beta-globin control primers. Amplified products were visualized under UV light after electrophoresis in $2 \%$ agarose gel, containing ethidium bromide and recorded in the system for image archiving and analysis (GeneSys, Syngene). Examination of M. genitalium DNA was performed by real-time PCR using the RealBest DNA Chlamydia trachomatis/Mycoplasma genitalium test (Vector-Best, Russia) according to the manufacturer's instruction. Reference strains $U$. urealyticum ATCC 27,618, U. parvum ATCC 27,815, and genomic DNA (ATCC33530D) of $M$. genitalium ATCC 33,530, M. fermentans ATCC 199989D, and M. pirum ATCC 25960D were used as positive controls.

\section{Statistical analysis}

Statistical analysis was performed in the Dell Statistica Version 13 (Dell INC. [2016] software.dell.com). Intergroup differences and age structure were analyzed using the chisquare test. $p$-values below 0.05 were considered as statistically significant. 
Table 2 PCR conditions and the primer sequences used for the detection of DNA U. parvum, $U$. urealyticum, $M$. hominis, $M$. pirum, and M. fermentans

\begin{tabular}{|c|c|c|c|}
\hline Species primers & Oligonucleotide sequence $5^{\prime}-3^{\prime}$ & $\begin{array}{l}\text { Product size } \\
\text { (bp) }\end{array}$ & Reference \\
\hline $\begin{array}{l}\text { U. parvum } \\
\text { UMS-57 } \\
\text { UMA-222 }\end{array}$ & $\begin{array}{l}5^{\prime} \text { - YAA ATC TTA GTG TTC ATA TTT TTT AC - 3' } \\
5^{\prime} \text { - GTA AGT GCA GCA TTA AAT TCA ATG- }{ }^{\prime}\end{array}$ & 326 & {$[5]$} \\
\hline $\begin{array}{l}\text { U. urealyticum } \\
\text { UMS-170 } \\
\text { UMA-263 }\end{array}$ & $\begin{array}{l}\text { 5' - GTA TTT GCA ATC TTT ATA TGT TTT CG- 3' } \\
5^{\prime} \text { - TTT GTT GTT GCG TTT TCT G- 3' }\end{array}$ & 476 & {$[5]$} \\
\hline $\begin{array}{l}\text { M. hominis } \\
\text { MHF } \\
\text { MHR }\end{array}$ & $\begin{array}{l}\text { 5'- ATA CAT CGA TGT CGA GCG AG-3' } \\
\text { 5'- CAT CTT TTA GTG GCG CCT TAC -3' }\end{array}$ & 270 & [6] \\
\hline $\begin{array}{l}\text { M. pirum } \\
\text { primer } 7 \\
\text { primer } 8\end{array}$ & $\begin{array}{l}5^{\prime} \text { - ATA CAT GCA AGT CGA TCG GA - 3' } \\
5^{\prime} \text { - ACC CTC ATC CTA TAG CGG TC - 3' }\end{array}$ & 180 & [7] \\
\hline $\begin{array}{l}M . \\
\text { fermentans } \\
\text { RW004 } \\
\text { RW005 }\end{array}$ & $\begin{array}{l}5^{\prime}-\text { GGA CTA TTG TCT AAA CAA TTT CCC - 3' } \\
5^{\prime}-\text { GGT TAT TCG ATT TCT AAA TCG CCT - 3' }\end{array}$ & 206 & [7] \\
\hline
\end{tabular}

PCR conditions:

U. parvum: $94^{\circ} \mathrm{C} / 3 \mathrm{~min}, 35 \times\left(95^{\circ} \mathrm{C} / 30 \mathrm{~s}, 58^{\circ} \mathrm{C} / 30 \mathrm{~s}, 72^{\circ} \mathrm{C} / 1 \mathrm{~min}\right), 72^{\circ} \mathrm{C} / 7 \mathrm{~min}$

U. urealyticum: $94^{\circ} \mathrm{C} / 3 \mathrm{~min}, 35 \times\left(95^{\circ} \mathrm{C} / 30 \mathrm{~s}, 55^{\circ} \mathrm{C} / 30 \mathrm{~s}, 72^{\circ} \mathrm{C} / 1 \mathrm{~min}\right), 72^{\circ} \mathrm{C} / 7 \mathrm{~min}$

M. hominis: $95^{\circ} \mathrm{C} / 10 \mathrm{~min}, 35 \times\left(94^{\circ} \mathrm{C} / 40 \mathrm{~s}, 58^{\circ} \mathrm{C} / 40 \mathrm{~s}, 72^{\circ} \mathrm{C} / 40 \mathrm{~s}\right), 72^{\circ} \mathrm{C} / 15 \mathrm{~min}$

M. pirum: $94^{\circ} \mathrm{C} / 2 \mathrm{~min}, 35 \times\left(94^{\circ} \mathrm{C} / 30 \mathrm{~s}, 55^{\circ} \mathrm{C} / 30 \mathrm{~s}, 72^{\circ} \mathrm{C} / 1 \mathrm{~min}\right), 72^{\circ} \mathrm{C} / 5 \mathrm{~min}$

M. fermentans: $94^{\circ} \mathrm{C} / 2 \mathrm{~min}, 35 \times\left(94^{\circ} \mathrm{C} / 30 \mathrm{~s}, 55^{\circ} \mathrm{C} / 45 \mathrm{~s}, 72^{\circ} \mathrm{C} / 50 \mathrm{~s}\right), 72^{\circ} \mathrm{C} / 5 \mathrm{~min}$

\section{Results}

The prevalence of urogenital mycoplasmas was found more often in men of the study group than in the control (28.2\% and $14 \%$ respectively, $p=0.05)$. Occurrence of urogenital mycoplasmas in the group of patients with urolithiasis (33.3\%) compared to control (14\%) has shown statistically significant difference $(p=0.03)$. Also in this study group, DNA of $U$. urealyticum was most frequently found, while in the remaining groups, U. parvum were more often observed (Fig. 1). In other groups, positive samples for Mycoplasma or Ureaplasma DNAs were also more often detected compared to control; however, the differences were not statistically significant (Table 3 ).

More than one Mycoplasma spp. was found in the same patient. $U$. parvum DNA occurred more frequently than other mycoplasmas. M. pirum and M. fermentans occurred with a low frequency only in the study groups; however, incidence of $M$. fermentans DNA was significantly higher in the urolithiasis group vs. controls $(p=0.03)$. In both groups, men with genitourinary tract diseases and control no DNA of the M. genitalium was found.

No relationship was found between the presence of urogenital mycoplasmas and the accompanying diseases or the results of laboratory tests in the study group. Age analysis had shown that positive results were more common in 21-30-year-old men compared to others $(p=0.05)$.

\section{Discussion}

The presence of mycoplasmas in the urogenital tract of women and men and the potential association of development of diseases has been studied for many years. The introduction of molecular biology methods and FVU as a diagnostic material increased the frequency of tests in men. Ureaplasma and Mycoplasma DNA occurs in a few percent of men without any symptoms of infection. The prevalence of $U$. urealyticum and $M$. hominis compared to control group in our study was reported: $9.4 \%(8 / 85)$ vs $4 \%(2 / 50)$ and $5.8 \%(5 / 85)$ vs $4 \%(2 / 50)$ respectively. Positive results for $U$. urealyticum in control groups performed by other authors were 2.5-8.0\% [8-11]; and for $M$. hominis, 1-6\% [11-16]. Most of these papers were based on infertility study and used sperm as a material for the investigation (not FVU), although the data performed by Gdoura et al. have shown that the results obtained from sperm and FVU were similar [17].

Among patients with urolithiasis occurrence of urogenital mycoplasmas was significantly more common compared to control group $-33.3 \%$ vs. $14 \%(p<0.05)$; $U$. urealyticum in this group was the most frequent. Only in urolithiasis group, $U$. urealyticum occurred more often than $U$. parvum. In published studies, $U$. urealyticum are more likely to cause symptomatic infections than $U$. parvum. Ureaplasma spp. may affect the formation of urinary stones leading to recurrent urolithiasis in patients by the 


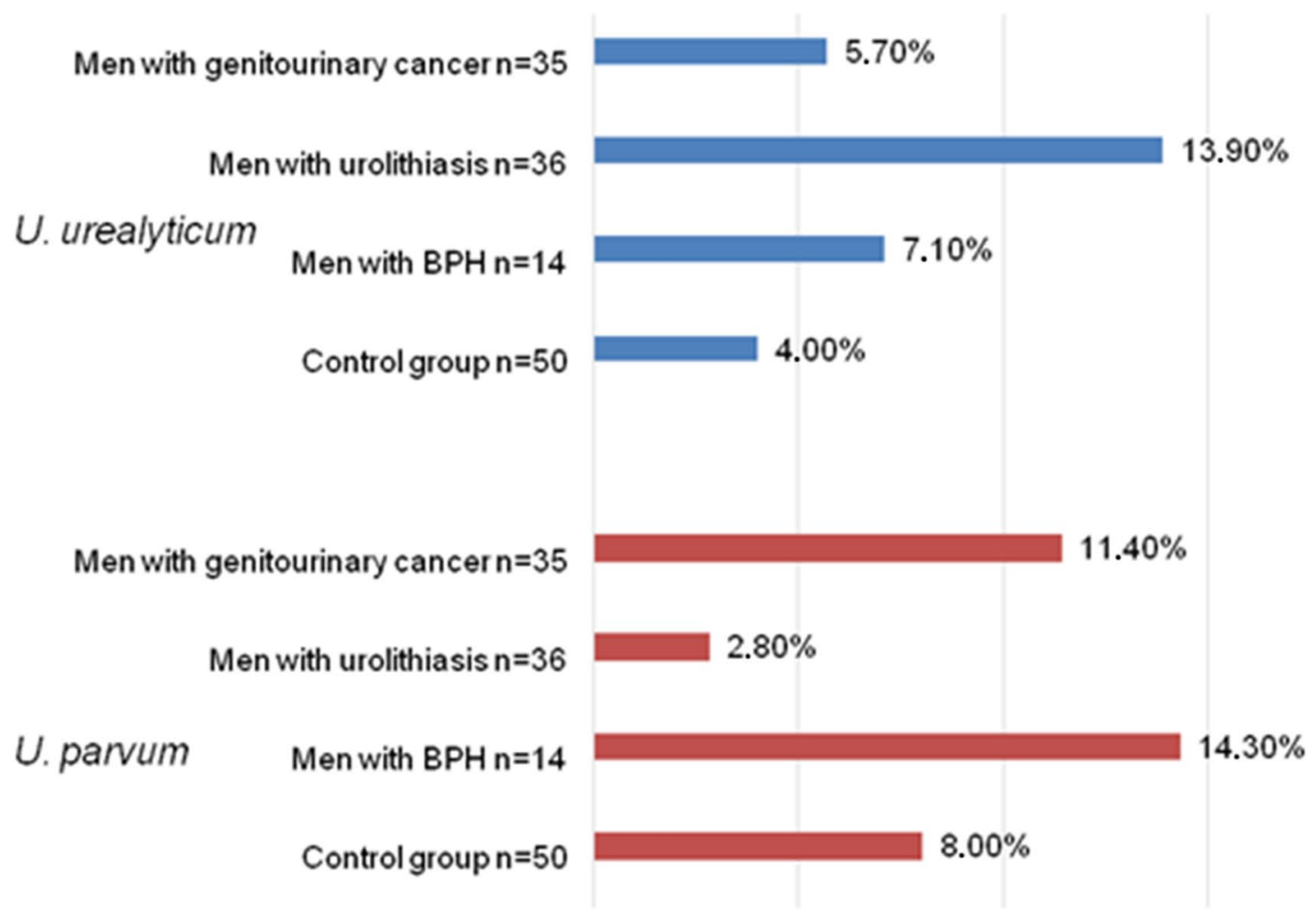

Fig. 1 Prevalence of Ureaplasma species in study groups

Table 3 Frequency of urogenital mycoplasmas

\begin{tabular}{llllll}
\hline & $\begin{array}{l}\text { Geni- } \\
\text { tourinary } \\
\text { cancer } \\
(n=35)\end{array}$ & $\begin{array}{l}\text { Urolithiasis } \\
(n=36)\end{array}$ & $\begin{array}{l}\text { BPH } \\
(n=14)\end{array}$ & $\begin{array}{l}\text { Total } \\
(n=85)\end{array}$ & $\begin{array}{l}\text { Control group } \\
(n=50)\end{array}$ \\
& $N(\%)$ & & & & \\
& $2(5.7)$ & $3(8.3)$ & $1(7.1)$ & $6(7.1)$ & $1(2)$ \\
\hline U. urealyticum & $4(11.4)$ & $1(2.8)$ & $2(14.3)$ & $7(8.2)$ & $3(6)$ \\
$U$. parvum & $1(2.9)$ & $3(8.3)$ & 0 & $4(4.7)$ & $1(2)$ \\
$M$. hominis & 0 & $1(2.8)$ & 0 & $1(1.2)$ & $1(2)$ \\
M. pirum & $2(5.7)$ & $2(5.5)$ & 0 & $4(4.7)$ & 0 \\
M. fermentans & 0 & $1(2.8)$ & 0 & $1(1.2)$ & 0 \\
$U$. urealyticum $+M$. hominis & 0 & $1(2.8)$ & 0 & $1(1.2)$ & 0 \\
U. urealyticum + M. fermentans & 0 & 0 & 0 & 0 & $1(2)$ \\
U. urealyticum $+U$. parvum $+M$. hominis & 0 & $12(33.3)$ & $3(21.4)$ & $24(28.2)$ & $7(14)$ \\
& $9(25.7)$ & $\# p=0.03$ & & $* p=0.05$ & \\
\hline
\end{tabular}

$p$ values $<0.05$ are considered as statistically significant

Total, patients with the following: genitourinary cancer, urolithiasis, BPH

$B P H$, benign prostatic hyperplasia

*Total vs. control group, \#Urolithiasis vs. control group creation of urease. In sterile normal urine, urease is not present; therefore, the basic condition for the formation of struvite stones in the urinary tract is the presence of urease-producing bacteria such as $U$. urealyticum. Under the influence of the urease produced, the $\mathrm{pH}$ of the urine changes to create a stone-friendly environment $[18,19]$. 
The role of Ureaplasma spp. in the production of urinary tract stones was also demonstrated in vivo in rats [20].

Molecular tests implemented for routine diagnostics in addition to species detected by microculture methods (Ureaplasma spp. and M. hominis) usually also include detection of M. genitalium. Occurrence of M. genitalium infection is $1-3 \%$ in men, according to community-based studies from the USA, UK, Scandinavia, and Australia [21-24]. In Miyake et al.'s study, the positive rate of $M$. genitalium in the group of man with human prostate cancer and BPH was very high $45.5 \%$ and $33.18 \%$ respectively [25]. However, the lack of positive results for $M$. genitalium in our study is not surprising for the group of patients without symptoms and inflammatory features of the genitourinary tract. Similar results were also confirmed by other authors. The low prevalence of M. genitalium in samples from infertile men and healthy men in control was also reported by Plecko et al. [26].

In our groups with benign prostatic hyperplasia and genitourinary cancer, the frequency of urogenital mycoplasmas detection was $21.4 \%$ and $25.7 \%$, respectively (in control - only 14\%). Miyake et al. in the group of man with human prostate cancer and BPH did not show the presence of $U$. urealyticum in examining surgical and biopsy specimens [27]. In these groups, infections are considered as a factor influencing on inflammation, progression of symptoms, or factors complicating the diagnostic or therapeutic process $[27,28]$.

Miyake et al. in the study included testing for the presence of $M$. hyorhinis DNA, although did not obtain positive results testing surgical specimens from man with prostate cancer and BPH [25]. Studies of M. pirum, $M$. penetrans, and M. fermentans (included our study) are rarely done, but can detected in patients with malignances and other genitourinary system diseases; however, further research is needed to clarify role of these microorganisms in etiology of mentioned diseases [29-31]. When there are difficulties in detecting the etiological agent in samples collected from patients with symptoms of infection, the presence of mentioned mycoplasmas is most often suspected; in such situation, extending the research on mycoplasmas may be positive.

The limitations of this study were as follows: small number of patients in groups and it is impossible to generalize our results; real-time PCR, which possessed higher sensitivity, was used only for detection of $M$. genitalium DNA. For other mycoplasmas, we used conventional PCR because real-time PCR tests, especially for M. pirum and $M$. fermentans, were not available, when this study was designed.

\section{Conclusions}

Higher percentage of urogenital mycoplasmas DNA in study group compared with control has been found in our study. In men with urolithiasis, DNA of urogenital mycoplasmas was significantly more frequent than in controls and $U$. urealyticum was most often detected, while in the remaining groups, $U$. parvum was most frequently observed. Incidence of $M$. fermentans was significantly higher in the urolithiasis group vs. controls.

It is important to consider urogenital mycoplasmas as a potential etiology of urogenital infection when clinical symptoms are present but etiology is unknown or uncertain.

Acknowledgements Thanks to Małgorzata Koźlik for help in collecting research materials. We would like to thank Prof. Jan Kowalski and Dr Renata Suchanek-Raif from the Department of Medical Genetics Faculty of Pharmaceutical Sciences in Sosnowiec Medical University of Silesia, Katowice, Poland, for help in real-time PCR procedure.

Author contribution All authors contributed to the study conception and design. Material preparation, data collection, and analysis were performed by Dominika Smolec and AlicjaEkiel. The first draft of the manuscript was written by Dominika Smolec and all authors commented on previous versions of the manuscript. All authors read and approved the final manuscript.

Funding This study was supported by Grant number PCN-2-o36/N/9/N of Medical University of Silesia, Katowice, Poland.

Data availability All data generated or analyzed during this study are included in this published article (and its supplementary information files).

\section{Declarations}

Ethics approval All procedures performed in studies involving human participants were in accordance with the ethical standards of the institutional and/or national research committee and with the 1964 Helsinki Declaration and its later amendments or comparable ethical standards. The study was approved by the Bioethical Committee of the Medical University of Silesia in Katowice (No. KNW/0022/KB1/48/14, KNW/022/KB1/48/I/14/16, KNW/0022/KB1/48/II/14/16/17).

Consent to participate Informed consent was obtained from all individual participants included in the study.

Consent to publish The participants have consented to the submission of the case report to the journal.

Conflict of interest The authors declare no competing interests.

Open Access This article is licensed under a Creative Commons Attribution 4.0 International License, which permits use, sharing, adaptation, distribution and reproduction in any medium or format, as long as you give appropriate credit to the original author(s) and the source, provide a link to the Creative Commons licence, and indicate if changes were made. The images or other third party material in this article are included in the article's Creative Commons licence, unless indicated otherwise in a credit line to the material. If material is not included in 
the article's Creative Commons licence and your intended use is not permitted by statutory regulation or exceeds the permitted use, you will need to obtain permission directly from the copyright holder. To view a copy of this licence, visit http://creativecommons.org/licenses/by/4.0/.

\section{References}

1. Gupta RS, Sawnani S, Adeolu M, Alnajar S, Oren A (2018) Phylogenetic framework for the phylum Tenericutes based on genome sequence data: proposal for the creation of a neworder Mycoplasmoidales ord. nov., containing two new families Mycoplasmoidaceae fam. nov. and Metamycoplasmataceae fam. nov. Harbouring Eperythrozoon, Ureaplasma and five novel genera. Antonie Van Leeuwenhoek 111:1583-1630. https://doi.org/10. 1007/s10482-018-1047-3

2. Jensen JS, Cusini M, Gomberg M, Moi H (2016) 2016 European guideline on Mycoplasma genitalium infections. J Eur Acad Dermatol Venereol 30:1650-1656. https://doi.org/10.1111/jdv. 13849

3. Hagiya H, Yoshida H, Yamamoto N, Kimura K, Ueda A, Nishi I, Akeda Y, Tomono K (2017) Mycoplasma hominis periaortic abscess following heart-lung transplantation. Transpl Infect Dis 19. https://doi.org/10.1111/tid.12697

4. Gerber L, Gaspert A, Braghetti A, Zwahlen H, Wutrich R, Zbinden R, Mueller N, Fehr T (2018) Ureaplasma and Mycoplasma in kidney allograft recipients-a case series and review of the literature. Transpl Infect Dis 20:e12937. https://doi.org/10.1111/tid. 12937

5. Bharat A, Cunningham SA, Budinger GRS, Kreise D, DeWet CJ, Gelman AE, Waites K, Crabb D, Xiao L, Bhorade1 S, Ambalavanan N, Dilling DF, Lowery EM, Astor T, Hachem R, Krupnick AS, DeCamp MM, Ison MG, Patel R (2015) Disseminated Ureaplasma infection as a cause of fatal hyperammonemia in humans. Sci Transl Med 22. https://doi.org/10.1126/scitranslmed.aaa8419

6. Kong F, Ma Z, James G, Gordon S, Gilbert GL (2000) Species identification and subtyping of Ureaplasma parvum and Ureaplasma urealyticum using PCR-based assays. J Clin Microbiol 38:1175-1179. https://doi.org/10.1128/JCM.38.3.1175-1179.2000

7. Nassar FA, Abu-Elamreen FH, Shubair ME, Sharif FA (2008) Detection of Chlamydia trachomatis and M. hominis, M. genitalium and $U$. urealyticum by polymerase chain reaction in patients with sterile pyuria. Adv Med Sci 53:80-86. https://doi. org/10.2478/v10039-008-0020-1

8. Wu J, Wang B, Zhou L, Xie Y, Xu J, Chen L, Yang T, Guo H (2013) Mycoplasmas infection in male HIV/AIDS patients in Jiangsu, China. Microb Pathog 63:54-58. https://doi.org/10. 1016/j.micpath.2013.06.003

9. Zeng W, Chen Q, Pi H, Mei Y, Wang L, Cao Y (2011) The investigation of two biovars of Ureaplasma urealyticum and antisperm antibody in infertile men. Shandong Med J 51:80-82

10. Zhang Q, Xiao Y, Zhuang W, Cheng B, Zheng L, Cai Y, Zhou H, Wang Q (2014) Effects of biovar I and biovar II of Ureaplasma urealyticum on sperm parameters, lipid peroxidation, and deoxyribonucleic acid damage in male infertility. Urology 84:87-92. https://doi.org/10.1016/j.urology.2014.04.014

11. Huang Ch, Long X, Jing S, Fan L, Xu K, Wang S, Zhu W (2016) Ureaplasma urealyticum and Mycoplasma hominis infections and semen quality in 19,098 infertile men in China. World J Urol 34:1039-1044. https://doi.org/10.1007/s00345-015-1724-z

12. Akgul A, Kadioglu A, Koksal MO, Ozmez A, Agacfidan A (2018) Sexually transmitted agents and their association with leucocytospermia in infertility clinic patients. Andrologia 50:e13127. https://doi.org/10.1111/and.13127

13. Huang C, Peng L, Zheng Z, Jiang Y (2014) Value of detection of Mycoplasma, Chlamydia and anti-sperm antibodies in male infertility. Int J Lab Med 35:1412-1414. https://doi.org/10.1111/ andr. 12078

14. Shi H, Chang Y (2005) Analysis of seminal parameter and Mycoplasma infection in infertile male. Chin J Derm Venereo J 19:358-359

15. Lee JS, Kim KT, Lee HS, Yang KM, Seo JT, Choe JH (2013) Concordance of Ureaplasma urealyticum and Mycoplasma hominis in infertile couples: impact on semen parameters. Urology 81:219-1224. https://doi.org/10.1016/j.urology.2013.02.044

16. Liu R, Wu Y (2004) The infection of Ureaplasma urealyticum and male infertility. Sichuan Med J 25:583-584

17. Gdoura R, Kchaou W, Ammar-Keskes L, Chakroun N, Sellemi A, Znazen A, Rebai T, Hammami A (2008) Assessment of Chlamydia trachomatis, Ureaplasma urealyticum, Ureaplasma parvum, Mycoplasma hominis, and Mycoplasma genitalium in semen and first void urine specimens of asymptomatic male partners of infertile couples. J Androl 29:198-206. https://doi.org/10.2164/ jandrol.107.003566

18. Bazin D, André G, Weil R, Matzen G, Emmanuel V, Carpentier X, Daudon M (2012) Absence of bacterial imprints on struvitecontaining kidney stones: a structural investigation at the mesoscopic and atomic scale. Urology 79:786-790. https://doi.org/10. 1016/j.urology.2011.08.054

19. Kokkayil P, Dhawan B (2015) Ureaplasma: current perspectives. Indian J Med Microbiol 33:205-214. https://doi.org/10.4103/ 0255-0857.154850

20. Yüce A, Yücesoy M, Yücesoy K, Canda T, Fadiloğlu M, Güre A, Yuluğ N (1996) Ureaplasma urealyticum-induced urinary tract stones in rats. Urol Res 24:345-348. https://doi.org/10.1007/ BF00389791

21. Slifirski JB, Vodstrcil LA, Fairley CK, Ong JJ, Chow E, Chen MY, Read T, Bradshaw CS (2017) Mycoplasma genitalium infection in adults reporting sexual contact with infected partners, Australia, 2008-2016. Emerg Infect Dis 3:1826-1833. https://doi.org/10. 3201/eid2311.170998

22. Sonnenberg P, IsonCA CS, Field N, Tanton C, Soldan K, Beddows S, Alexander S, Khanom R, Saunders P, Copas AJ, Wellings K, Mercer KH, Johnson AM (2015) Epidemiology of Mycoplasma genitalium in British men and women aged 16-44 years: evidence from the third National Survey of Sexual Attitudes and Lifestyles (Natsal-3). Int J Epidemiol 44:1982-1994. https://doi.org/10. 1093/ije/dyv194

23. Andersen B, Sokolowski I, Østergaard L, Kjølseth Møller J, Olesen F, Jensen JS (2007) Mycoplasma genitalium: prevalence and behavioural risk factors in the general population. Sex Transm Infect 83:237-241. https://doi.org/10.1136/sti.2006.022970

24. Manhart LE, Holmes KK, Hughes JP, Houston LS, Totten PA (2007) Mycoplasma genitalium among young adults in the United States: an emerging sexually transmitted infection. Am J Public Health 97:1118-25. https://doi.org/10.2105/AJPH.2005.074062

25. Miyake M, Ohnishi K, Hori S, Nakano A, Nakano R, Yano H, Ohnishi S, Owari T, Morizawa Y, Itami Y, Nakai Y, Inoue T, Anai S, Torimoto K, Tanaka N, Fujii T, Furuya H, Rosser CJ, Fujimoto K (2019) Mycoplasma genitalium infection and chronic inflammation in human prostate cancer: detection using prostatectomy and needle biopsy specimens. Cells 8(3):212. https://doi.org/10. 3390/cells8030212

26. Plecko V, Zele-Starcevic L, Tripkovic V, Skerlev M, Ljubojevic S, Plesko S, Marekovic I, Jensen JS (2014) Unusually low prevalence of Mycoplasma genitalium in urine samples from infertile men and healthy controls: a prevalence study. BMJ Open 4:e005372. https://doi.org/10.1136/bmjopen-2014-005372 
27. Langan RC (2019) Benign prostatic hyperplasia. Prim Care 46(2):223-232. https://doi.org/10.1016/j.pop.2019.02.003

28. Namiki K, Goodison S, Porvasnik S, Allan RW, Iczkowski KA, Urbanek C, Reyes L, Sakamoto N, Rosser CJ (2009) Persistent exposure to Mycoplasma induces malignant transformation of human prostate cells. PLoS ONE 4(9):e6872. https://doi.org/10. 1371/journal.pone.0006872

29. Bauer FA, Wear DJ, Angritt P, Lo SC (1991) Mycoplasma fermentans (incognitus strain) infection in the kidneys of patients with acquired immunodeficiency syndrome and associated nephropathy: a light microscopic, immunohistochemical, and ultrastructural study. Hum Pathol 22(1):63-69. https://doi.org/10.1016/ 0046-8177(91)90063-u

30. Barykova YA, Logunov DY, Shmarov MM, Vinarov AZ, Fiev DN, Vinarova NA, Rakovskaya IV, Baker PS, Shyshynova I,
Stephenson AJ, Klein EA, Naroditsky BS, Gintsburg AL, Gudkov AV (2011) Association of Mycoplasma hominis infection with prostate cancer. Oncotarget 2(4):289-97. https://doi.org/10.18632/ oncotarget.256

31. Preiswerk B, Imkamp F, Vorburger D, Hömke RV, Keller PM, Wagner K (2020) Mycoplasma penetrans bacteremia in an immunocompromised patient detected by metagenomic sequencing: a case report. BMC Infect Dis 20(1):7. https://doi.org/10.1186/ s12879-019-4723-7

Publisher's note Springer Nature remains neutral with regard to jurisdictional claims in published maps and institutional affiliations. 